\title{
A Romantic Flower in the Era of Critical Realism
}

\author{
Yuxuan Yuan*, Jirong Shen \\ Nanjing Normal University, Nanjing 210000, Jiangsu Province, China
}

*Corresponding author: Yuxuan Yuan, 2900426082@qq.com

\begin{abstract}
Most of Mark Twain's works criticize reality in a humorous but sharp tone. However, The Diaries of Adam and Eve, which was published in his later life, depicts the wonderful life of a man and a woman, narrating a touching love story. This article analyzes this unique piece of work from the angle of romanticism, highlighting its charm.
\end{abstract}

Keywords: Literature; Romanticism; Mark Twain; The Diaries of Adam and Eve

Publication date: October 2021; Online publication: October 29, 2021

\section{Introduction}

Mark Twain, famous for his deep and acrid tone of irony and criticism, was the founder and pioneer of critical realism. In essence, his writings exposed the corrupted truth of the so-called "golden age" of capitalism after the abolishment of slavery in the United States as well as the role of money in the capitalist world with a humorous and witty writing style, mocking the absurdity of American democracy and the hypocritical nature of the democrat's paradise ${ }^{[1]}$. Compared with his other well-known works like The Adventures of Tom Sawyer and Running for Governor, The Diaries of Adam and Eve is less well-known to the world, thus having relatively few literature reviews and comments on this book. Published during Mark Twain's twilight years, The Diaries of Adam and Eve was distinctive from his other works, which possessed clear characteristics of critical realism. Mark Twain narrated the love story between Adam and Eve from the bible in the form of a diary. This piece of work, which is beautiful and touching, possess some characteristics of romanticism. This article employs the theory of romanticism to analyze The Diaries of Adam and Eve by Mark Twain in order to explore the meaning and his purpose of writing this book as well as to examine the feelings that can be revealed through this book.

\section{Research tools}

Romanticism refers to the use of a magnificent imagination, passionate language, and an exaggerated method to shape an image. Beginning from the authors' subjective inner world, writers of romanticism would have had expressed their passionate pursuit of the ideal world with rich imagination. Compared with realism, the most significant difference lies in the writing technique, where writings of romanticism contain a passionate pursuit of dreams and purposes, thus bringing into light the passion and enthusiasm hidden in the authors' heart ${ }^{[2]}$. They also incite a positive feeling among readers; this the main reason why this kind of writing is popular among both authors and readers.

Realism first originated in Europe as an inheritance and counter to romanticism. When it arrived in America, realism found a fertile soil in the historical background at that time - the westward movement, industrialization, and the abolishment of slavery. After the Civil War, America became a united country. The rapid development of both the economy and the society fostered and enhanced realism. Beneath the flourishing and thriving plane, a series of problems surfaced. Several writers began to pay attention to 
people's sufferings and uncovered the dark reality, which augmented the growth of critical realism. Mark Twain was the most renowned writer of critical realism at America in the late 19th century. Nevertheless, The Diaries of Adam and Eve was a piece of work which reflected the remaining influence of romantism. The Diaries of Adam and Eve was a "romantic flower" not only of Mark Twain's works, but also at that beginning stage of critical realism.

\section{Romanticism in The Diaries of Adam and Eve}

\subsection{Expression of subjective feelings}

The most prominent feature of romanticism is the expression of strong personal feelings by writers through their works. As Engels had said, "What people achieved after the French Revolution was not the freedom, equality, and fraternity promised by those bourgeois thinkers, but a social satire full of human desires and moral decay. People's belief in God, the expectation of the future, and the curse of the reality, all combined into a strong emotional flow - romanticism ${ }^{[3]}$." That was why romanticism possessed such a characteristic. In The Diaries of Adam and Eve, Mark Twain mainly expressed two emotions - one was his love and the memory of his beloved wife, and the other, his praise for humans' pure love.

"In that case, I think I could enjoy looking at her ${ }^{[4]}$." From his initial dislike toward Eve as an intruder, Adam gradually realized Eve's beauty. In Adam's eyes, Eve was beautiful and charming, thus awakening Adam's love for Eve. This situation is similar to when Mark Twain first met his future wife - Olivia Langdon. During his 30s, Mark Twain had planned to visit Europe and the Middle East, aboard the steamship Quaker City. It was on this ship that he first saw a photograph of Livy. Twain later claimed that he fell in love with the young lady at first sight. The scene where Adam watches Eve reflected Mark Twain's memory of his first meeting with Olivia Langdon. In Eve's diary, in her entry on Wednesday, she took the task of naming all the things from Adam. To a certain extent, she outperformed Adam and was skillful at working. "The minute I set eyes on an animal I know what it is. I don't have to reflect a moment ${ }^{[4]}$." In Mark Twain's life, Olivia assisted him in many aspects too. She helped him edit manuscripts, change several phrases which she considered indecent, sort out his letters, and attend to his social as well as daily affairs. By describing Eve aiding Adam, Twain expressed his gratitude to his beloved, hardworking wife ${ }^{[4]}$. Eve (Olivia) spent her whole life endeavoring to make Adam (Mark Twain) realize that his happiness could not be achieved without her love and company, and his happiness could only be achieved with her presence. Losing Eve was in fact losing Eden itself. It was because of his deep love for Olivia that Mark Twain felt extremely painful when Olivia passed away. At Eve's grave, Adam wrote, "Wheresoever she was, there was Eden ${ }^{[4]}$." We could only imagine how sorrowful Mark Twain was when Olivia died of a heart attack on June 5, 1904, in their apartment at Florence, Italy. Twain was in great sorrow. When reading the last sentence of this book, readers could feel Twain's endless sorrow and his love for Olivia.

"Wheresoever she was, there was Eden ${ }^{[4] " ; ~ t h i s ~ i s ~ t h e ~ e t e r n a l ~ s o n g ~ o f ~ l o v e ~ b e t w e e n ~ m e n ~ a n d ~ w o m e n ~}$ of the world. The relationship that Mark Twain portrayed between Adam and Eve was the most primitive relationship between men and women. There were no other factors involved, such as skin color, country, nationality, class, family, cultural concept, educational background, occupation, property, etc. Mark Twain identified Adam and Eve as the main characters of his work, extracting all those factors to see what is left and the most essential thing in a relationship between a man and woman. The attraction between two genders is the law of nature. When Adam and Eve first met, they were not on good terms. They disliked each other but soon, fell in love. Without factors such as the pressure from the government's legal system, social customs, the pleas of their parents and relatives, they were naturally inseparable from each other. Mark Twain praised this kind of pure love - the natural attraction. By depicting pure love, Mark Twain has given some inspiration to the people at that time about the essence of love. 


\subsection{Portrayal of nature}

Romantic literatures tend to emphasize the love for nature, respect for primitivism, and valuing the common, "natural" man. Romantics idealize country life and believe that many of the ills of society are results of urbanization. Most romantic writers regard nature as a spiritual support. They glorify nature, despise the ugly reality, compare the "beauty" of nature with the "ugliness" of reality, and praise the simple beauty of nature ${ }^{[2]}$.

Through The Diaries of Adam and Eve, Mark Twain expressed an idea that men are of nature and men should treat nature in awe. Only in this way, can human coexist with nature harmoniously, and enjoy the beauty as well as gifts of nature. Twain criticized the arrogant mindset of looking down upon nature and viewing human as the center of the world. He yearned for an ideal society where humans and nature can live in harmony. In order to convey the idea of respecting nature, Mark Twain depicted vivid characters. The characteristics of Adam and Eve differed vastly. In the beginning, Adam was unsociable and had no interest for the outside world as he always said, "Pulled through. This day is getting to be more and more trying ${ }^{[4]}$." On the other hand, Eve's world was rich and colorful. She was full of curiosity about nature and had a tireless pursuit for beauty. She longed for communing with her fellows and regarded all that was in nature as her friends. She often walked alongside the lake and reveled in the beauty of nature. From the day Eve was created, she developed a strong interest in Adam and the nature around her. The stars and moon were her friends, and the animals were close to her. It showed her subjective initiative in exploring the world when she took on the responsibility of naming all the things from Adam. Eve's attitude toward nature was modest and genuine. This also represented Mark Twain's attitude toward nature, where all human beings are mother nature's children, and it is only proper that humans remain humble.

\subsection{Interests in the medieval past}

Most romantic writers had attached great importance to traditional folk literature, and their interests for the mysterious history, colorful folklore, and folk ballads of the Middle Ages were exceedingly remarkable. They opposed classicism as it only pursues elegance but excludes folk art. Many writers began their work by collecting folk songs, ballads, and folk tales. The most distinctive feature of the medieval period was religion. People of all classes, from Kings to lords to knights to common people, could only think and live within the framework of religion, and they were never allowed to transcend it. The whole medieval Western European culture, including the Early Renaissance, took Christianity as the subject and the Christian thought as the background. The main body of the medieval culture in Western Europe was the Christian culture and the spiritual backbone of the Christian culture was the bible.

The Diaries of Adam and Eve was based on the book of Genesis. Instead of following the original theme in Genesis - sin and punishment of human, Mark Twain's book focused on the two characters Adam and Eve. The course of Adam and Eve from meeting to understanding to loving each other was recorded in the diaries using simple and plain language. In Genesis, the psychological events of Adam and Eve had never been revealed. In Mark Twain's writing, the story of Adam and Eve was no longer a tragedy of crime and punishment; instead, it became a romantic legend, where love affairs were clearly depicted from being acquaintances to developing mutual love. Adam and Eve, though inspired from the book of Genesis, were very different from the ones of the bible in both thought and action. The whole of Genesis praises the greatness of God in His creation and reveals the source of sin. The Eve in Genesis was always obedient to God's arrangement and to Adam, her husband. However, in Mark Twain's book, Eve was enthusiastic, curious, and active. Her curiosity about the surroundings drove her to gradually know and understand Adam, and finally fall in love with him. She took the initiative to attract Adam's attention, show her kindness, even at the cost of "trying to clod apples out of that forbidden tree ${ }^{[4]}$." The brave and passionate Eve was far better than the Eve in the bible. Choosing the story of Adam and Eve from the bible 
showed Mark Twain's interest in the medieval past, which was a feature of romanticism, but more importantly, Twain's depiction of the new Eve and the romantic relationship between Adam and Eve reflected his affirmation of humans as independent individuals as well as his questionable attitude toward religion in challenging God's authority ${ }^{[5]}$. This corresponded to the core of romanticism - the emphasis of individuals' freedom and emotions.

\section{Conclusion}

This article analyzes The Diaries of Adam and Eve by Mark Twain from the perspective of romanticism. Although the book was published at the time when critical realism prevailed, after careful and comprehensive review, it was found that this book possessed many romantic characteristics. It is like a romantic flower in the era of critical realism. First, in this book, Twain expressed his sincere feelings - his love and memory of his beloved wife, and his praise for the pure love of humans. Second, he also showed his attitude toward nature that man is of nature and men should treat nature in awe, representing an advanced ecology view. Third, based on the story from the bible, Mark Twain made vast changes, emphasizing humans' freedom and emotions. Unlike his other works with themes of criticizing American hypocritical politics, pathological morality, and sanctimonious religion with an ironic humor, The Diaries of Adam and Eve is full of vigor and love. The touching and tragic ending for Adam broadened and deepened the connotation of this work, making it more meaningful. This literature review might not be as comprehensive but the angle from which The Diaries of Adam and Eve was analyzed has profound research value.

\section{Disclosure statement}

The authors declare that there is no conflict of interest.

\section{References}

[1] Tan HJ, 2005, On Mark Twain's Diaries of Adam \& Eve. Journal of Xiangtan University (Philosophy and Social Sciences), (04): 111-115.

[2] Sang Y, 2010, A Brief Analysis of Romanticism Literature and Its Creation Characteristics. Times Literature, (03): 263-264.

[3] Xu B, 2003, Fifteen Lectures on Western Literature, Peking University Press, Peking.

[4] Mark Twain, 2000, The Diaries of Adam \& Eve, Prometheus Books.

[5] Cai J, Xu J, 2007, An Interpretation of Mark Twain's Religious Ideas through The Diary of Adam and Eve. An Interpretation of Mark Twain's Religious Ideas through The Diary of Adam and Eve, (04): 4648. 